\title{
KEJADIAN OTITIS EKSTERNA PADA MASYARAKAT PENEBEL TABANAN DAN YANGAPI BANGLI YANG BERKUNJUNG KE BAKTI SOSIAL STAF MEDIS FUNGSIONAL TELINGA HIDUNG TENGGOROKAN FAKULTAS KEDOKTERAN UNIVERSITAS UDAYANA - RUMAH SAKIT UMUM PUSAT SANGLAH PADA TAHUN 2012
}

\author{
Putu Teguh Aryanugraha ${ }^{1}$, Eka Putra Setiawan ${ }^{2}$ \\ ${ }^{1}$ Program Studi Pendidikan Dokter, Fakultas Kedokteran Universitas Udayana,
} ${ }^{2}$ SMF THT-KL Rumah Sakit Umum Pusat Sanglah/Fakultas Kedokteran Universitas Udayana

\section{ABSTRAK}

Negara indonesia adalah negara yang beriklim tropis yang di beberapa tempat memiliki suhu dan kelembaban yang memiliki kriteria faktor predisposisi terjadinya otitis eksterna (OE) yang biasanya dipicu oleh tumbuhnya jamur yang merupakan penyebab awal terjadinya otitis eksterna. Penelitian dilakukan di dua tempat yaitu di Desa Penebel, Tabanan dan di Desa Yangapi Bangli. Tujuan dari penelitian ini untuk mengetahui prevalensi otitis eksterna khususnya pada masyarakat yang mengikuti bakti sosial di Desa Penebel dan Yangapi. Penelitian ini dilakukan dengan rancangan deskriptif kuantitatif dengan populasi terjangkau yakni masyarakat Desa Penebel dan Yangapi yang datang ke bakti sosial SMF THT-KL rumah sakit sanglah. Insiden terjadinya OE di Desa Penebel adalah 6 dari 66 pasien dan di Desa Yangapi adalah 3 dari 96 pasien. Variasi kejadian OE di Desa Penebel sama banyak antara pasien laki - laki dan perempuan dengan rentang umur 41 tahun keatas, sedangkan kejadian OE di Desa Yangapi lebih banyak pada laki - laki dengan rentang usia $21-30$ tahun. Pada penelitan ini didapatkan hasil pasien otitis eksterna yang datang ke Baksos di kedua desa sebanyak 9 orang dari 162 pasien yang datang ke bakti sosial SMF THT-KL RSUP Sanglah.

Kata Kunci: Otitis eksterna, Jenis Kelamin, Usia, Masyarakat Desa Penebel dan Yangapi.

\section{INCIDENCE RATE OF OTITIS EXTERNA IN SOCIETY OF PENEBEL AND YANGAPI BANGLI WHO VISITED THE SOCIAL ACTIVITY EAR NOSE THROAT DIVISION FACULTY OF MEDICINE UDAYANA UNIVERSITY- SANGLAH GENERAL HOSPITAL IN 2012}

\begin{abstract}
Indonesia is a tropical country which in some places have there own temperature and humidity criteria factors predisposing to otitis externa is usually triggered by the growth of fungi that are responsible for the onset of otitis externa. The research was conducted in two places, namely in the village of Penebel Tabanan and the village of Yangapi Bangli. The aim to determine the prevalence of otitis externa, especially in people who follow social events in the village Penebel and Yangapi. This research was carried out by quantitative descriptive design with a population that is affordable and Yangapi Penebel villagers who come to charity ENT Division Sanglah Hospital. The incidence of OE in the village Penebel was 6 of 66 patients and in the village Yangapi was 3 of 96 patients. Variants $\mathrm{OE}$ in the village of the same Penebel lot of male patients men and women with a lifespan of 41 years and above, whereas the incidence in the village OE Yangapi more on men with an age range 21-30 years. At this research showed otitis externa patients who come to social event in both villages were 9 people from 162 patients who came to the social event ENT Division Sanglah Hospital.
\end{abstract}

Keywords : Otitis externa, Gender, Age, people of Penebel and Yangapi village. 


\section{PENDAHULUAN}

Negara Indonesia adalah negara tropis dengan ciri musim panas udara sangat panas, musim dingin udara sangat dingin sehingga bisa menyebabkan penyakit-penyakit dibidang THTKL. ${ }^{1,2}$ Berikutnya ada faktor lain yang lebih penting yaitu kelembaban udara, di daerah tropis kelembapan udaranya tinggi sedangkan di daerah sub tropis kelembapan udaranya rendah.

Otitis eksterna merupakan infeksi yang terjadi akibat bakteri yang menyebabkan radang pada telinga bagian luar. Otitis eksterna adalah radang liang telinga akut maupun kronis disebabkan oleh bakteri dapat terlokalisir atau difus. Faktor ini penyebab timbulnya otitis eksterna dapat berupa kelembaban, penyumbatan liang telinga, trauma lokal dan alergi., ${ }^{1,3}$ Faktor ini menyebabkan berkurangnya lapisan protektif yang menyebabkan edema dari epitel skuamosa. Keadaan ini menimbulkan trauma lokal yang mengakibatkan bakteri masuk melalui kulit, inflasi dan menimbulkan eksudat. ${ }^{1,2}$ Bakteri patogen pada otitis eksterna akut adalah pseudomonas (41\%), strepokokus (22\%), stafilokokus aureus (15\%) dan bakteroides (11\%). Istilah otitis eksterna akut meliputi adanya kondisi inflasi kulit dari liang telinga bagian luar. ${ }^{4,5}$

Penyakit ini sering dijumpai pada daerahdaerah yang panas dan lembab serta jarang pada iklim-iklim sejuk dan kering. Patogenesis dari otitis eksterna sangat komplek dan sejak tahun 1844 banyak peneliti mengemukakan faktor pencetus dari penyakit ini seperti Branca (1953) mengatakan bahwa berenang merupakan penyebab dan menimbulkan kekambuhan. Senturia (1984) menganggap bahwa keadaan panas, lembab dan trauma terhadap epitel dari liang telinga luar merupakan faktor penting untuk terjadinya otitis eksterna. Howke (1984) mengemukakan pemaparan terhadap air dan penggunaan lidi kapas dapat menyebabkan terjadi otitis eksterna baik yang akut maupun kronik. ${ }^{1,3,4,6}$

Setiap tahun otitis eksterna terjadi pada 4 dari setiap 1000 orang di Amerika Serikat. Kejadian lebih tinggi selama musim panas, mungkin karena partisipasi dalam kegiatan air lebih tinggi. Otitis eksterna akut maupun kronis, daneczematous merupakan otitis yang umum di Amerika Serikat, namun otitis necrotizing jarang terjadi. ${ }^{6}$ Sebuah studi epidemiologi tunggal di Inggris menemukan prevalensi selama 12-bulan yang sama untuk individu yang berusia 5-64 tahun dan prevalensinya meningkat pada usia lebih dari 65 tahun. ${ }^{6,7}$ Secara umum di dunia frekuensi otitis eksterna tidak diketahui, namun insidennya meningkat di negara tropis seperti Indonesia. Tidak ada ras ataupun jenis kelamin yang berpengaruh terhadap angka kejadian otitis eksterna. Umumnya, tidak ada hubungan antara perkembangan otitis eksterna dan usia. ${ }^{1,5}$ Prevalensi otitis eksterna di Indonesia belum di ketahui pasti, namun kejadian otitis eksterna sering terjadi di negara tropis seperti Indonesia. Di Indonesia otitis eksterna dapat ditemukan pada semua kelompok usia, insiden tertinggi ditemukan pada anak usia 7 hingga 12 tahun. ${ }^{1,5,7}$

Pencarian data tentang prevalensi otitis eksterna merupakan hal yang penting untuk menentukan kondisi kesehatan masyarakat. Berkenaan dengan itu dalam rangka pelaksanaan Bakti Sosial di Desa Penebel Tabanan dan Desa Yangapi Bangli perlu dilaksanakan sebuah studi yang bertujuan untuk mengetahui prevalensi otitis eksterna khususnya pada masyarakat yang mengikuti baksos di Desa Penebel dan Yangapi.

METODE

Penelitian ini menggunakan rancangan deskriptif kuantitatif dengan populasi adalah masyarakat Desa Penebel Tabanan dan Desa Yangapi Bangli. Populasi terjangkau adalah masyarakat Desa Penebel Tabanan dan Desa Yangapi Bangli yang datang ke tempat baksos.

Langkah-langkah yang dilakukan dengan formulir isian, pemeriksaan dilakukan oleh dokter THT-KL dan dokter residen THT-KL, sarana yang diperlukan seperti lampu kepala, otoskop, lidi dan kapas, sendok serumen, $\mathrm{H} 2 \mathrm{O} 2$, alkohol. Kartu pasien yang telah diisi oleh dokter yang memeriksa dikumpulkan oleh peneliti dan dianalisis dalam bentuk presentase jenis kelamin, umur, dan distribusi. Kriteria inklusi penelitian ini adalah masyarakat yang datang ketempat bakti sosial mengisi formulir dan diperiksa. Kriteria eksklusi pada penelitian ini adalah masyarakat yang tidak datang, formulir tidak terisi lengkap, datang dari luar wilayah. Kegiatan ini di lakukan pada tanggal 4 November 2012 di Puskesmas Penebel 1 Desa Penebel Tabanan dan tanggal 11 November 2012 
di SD Negeri 3 Yangapi Desa Yangapi Bangli. Data yang didapatkan kemudian dianalisis secara univariat menggunakan perangkat lunak komputer. Hasil analisa dijabarkan dalam bentuk tabel berdasarkan jenis kelamin dan usia terhadap kejadian OE di desa masing - masing.

\section{HASIL}

Karakteristik Pasien pada penelitian ini adalah sebagai berikut.

Dari Tabel 1, didapatkan responden berjumlah 66 dari Desa Penebel yang terdiri dari 33 laki-laki dan 33 perempuan. Dari Desa Yangapi didapatkan 49 laki-laki dan 47 perempuan.

Di Desa Penebel, distribusi umur paling banyak pada kelompok umur 61 tahun ke atas sebanyak 20, lalu 41-50 tahun sebanyak 19 orang, dan 51-60 tahun sebanyak 14 orang. Di Desa
Yangapi, distribusi umur paling banyak pada kelompok umur 0-10 tahun sebanyak 57 orang, lalu 11-20 tahun sebanyak 14 orang, dan kelompok umur 41-50 tahun sebanyak 8 orang.

Pasien yang didiagnosis Otitis Eksterna (OE) sebanyak 6 orang di Desa Penebel dan sebanyak 3 orang di Desa Yangapi. Dari 6 orang pasien OE di Desa Penebel, berdasarkan jenis kelamin, 3 orang adalah laki-laki dan 3 orang perempuan. Sedangkan menurut kelompok umur, 3 orang dari kelompok umur 41-50 tahun dan 3 orang dari kelompok umur 61 tahun ke atas. Dari 3 orang pasien OE di Desa Yangapi, berdasarkan jenis kelamin, 2 orang adalah laki-laki dan 1 orang perempuan. Sedangkan menurut kelompok umur, 1 orang dari kelompok umur 0-10 tahun dan 2 orang dari kelompok umur 21-30 tahun.

Tabel 1. Karakteristik pasien berdasarkan jenis kelamin dan umur

\begin{tabular}{lcc}
\hline \multicolumn{1}{c}{ Karakteristik } & Jumlah (orang) & \\
\cline { 2 - 3 } Jenis Kelamin: & Desa Penebel & Desa Yangapi \\
Laki - Laki & 33 & 49 \\
Perempuan & 33 & 47 \\
\hline Umur: & & 57 \\
0-10 tahun & 3 & 14 \\
11-20 tahun & 2 & 3 \\
21-30 tahun & 2 & 7 \\
31-40 tahun & 6 & 8 \\
41-50 tahun & 19 & 1 \\
51-60 tahun & 14 & 6 \\
61 tahun - ke atas & 20 & 3 \\
\hline Diagnosa: & & \\
OE & 6 & \\
\hline
\end{tabular}

Tabel 2. Jumlah pasien OE berdasarkan jenis kelamin dan umur

\begin{tabular}{ccc}
\hline \multicolumn{1}{c}{ Karakteristik } & \multicolumn{2}{c}{ Jumlah Diagnosis OE (orang) } \\
\cline { 2 - 3 } & Desa Penebel & Desa Yangapi \\
\hline Jenis Kelamin: & 3 & 2 \\
Laki - Laki & 3 & 1 \\
Perempuan & & \\
\hline Umur: & 0 & 1 \\
0-10 tahun & 0 & 0 \\
11-20 tahun & 0 & 2 \\
21-30 tahun & 0 & 0 \\
31-40 tahun & 0 & 0 \\
$41-50$ tahun & 3 &
\end{tabular}




$\begin{array}{lll}51-60 \text { tahun } & 0 & 0 \\ 61 \text { tahun }- \text { ke atas } & 3 & 0\end{array}$

\section{PEMBAHASAN}

Pada Baksos SMF THT-KL RS Sanglah di Desa Penebel Tabanan di dapatkan pasien berjumlah 66 orang dengan karakteristik pasien yang didominasi oleh pasien yang berumur di atas 50 tahun sebanyak 34 pasien (51,5\%). Diagnosis yang di dapat dari keseluruhan pasien yakni otitis eksterna sebanyak 6 orang, obstruksi serumen 10 orang, otitis media sebanyak 14 orang, diagnosis lain 32 orang, dan tht tenang sebanyak 4 orang. Dari 6 orang yang didiagnosis otitis eksterna didapatkan pasien laki-laki sebanyak 3 orang dan pasien perempuan sebanyak 3 orang.

Sedangkan pada Baksos SMF THT-KL RS Sanglah di Desa Yangapi Bangli didapatkan pasien berjumlah 96 orang dengan karakteristik pasien yang didominasi oleh pasien yang berumur di bawah 10 tahun sebanyak 57 pasien (59,3\%). Diagnosis yang di dapat dari keseluruhan pasien yakni otitis eksterna sebanyak 3 orang, obstruksi serumen 20 orang, otitis media sebanyak 3 orang, diagnosis lain 50 orang, dan tht tenang sebanyak 20 orang. Dari 3 orang yang didiagnosis otitis eksterna didapatkan pasien laki-laki sebanyak 2 orang dan pasien perempuan sebanyak 1 orang.

Pada Desa Penebel Tabanan memiliki suhu $29^{\circ} \mathrm{C}$ dengan ketinggian 358 meter di atas permukaan laut dan kelembaban $60 \%$. Sedangkan pada Desa Yangapi Bangli memiliki suhu $27^{\circ} \mathrm{C}$ dengan ketinggian 400 meter di atas permukaan laut dan kelembaban 63\%. Desa Yangapi memiliki suhu lebih rendah dari pada Desa Penebel namun memiliki kelembapan yang lebih tinggi yang memungkinkan tumbuhnya jamur. Ini menunjukan bahwa suhu dan kelembapan masih dalam batas normal namun masih memungkinkan tumbuhnya jamur yang bisa menyebabkan otitis eksterna sehingga suhu dan kelembapan masih menjadi salah satu faktor penyebab otitis eksterna di Desa tersebut.
Perbedaan karakteristik pasien yang didapat pada Desa Penebel dan Yangapi terjadi karena di Desa Yangapi Baksos diadakan di sekolah dasar sehingga lebih menarik minat pasien anakanak. Berbeda dengan baksos di Desa Penebel yang pelaksanaannya bertempat di Puskesmas desa. Di kedua desa didapatkan diagnosis otitis eksterna dengan proporsi yang kecil yakni 9\% pada Desa penebel dan 3\% pada Desa Yangapi. Dari keseluruhan pasien otitis ekterna secara umum datang dengan keluhan nyeri pada liang telinga luar. Pada penelitan ini secara umum pasien yang datang ke baksos memiliki keluhan THT sehingga terdapat potensi yang besar tidak didapatkannya otitis eksterna yang asimtomatik pada umumnya.

Berdasarkan penelitian di beberapa rumah sakit pendidikan di Indonesia, angka kejadian otitis eksterna berkisaran $8 \%-9 \%$, dari seluruh pengunjung klinik THT di RSUP Dr. Kariadi periode 1974-1978, dari jumlah kunjungan 57.289, terdapat 4.640 atau $8,08 \%$ penderita, dan berdasarkan data rawat jalan penderita 1998-1999 terdapat kunjungan 34.193 penderita, dan penderita yang didiagnosis sebagai otitis eksterna 1604 orang atau 3,45\%. Di RSUP Dr. Soetomo, Surabaya, terdapat 7.667 kunjungan yaitu $8,88 \%$ dari seluruh kunjungan ke klinik THT yaitu 88.166 orang pasien.

\section{SIMPULAN}

Pada penelitan ini didapatkan hasil pasien otitis eksterna yang datang ke baksos di kedua desa sebanyak 9 orang dari 162 pasien yang datang ke baksos SMF THT-KL RS Sanglah. Saran pada penelitian selanjutnya untuk melakukan sosialisasi kepada warga untuk datang ke tempat penelitian sehingga kejadian otitis eksterna yang asimtomatik bisa didapatkan. Disarankan pula dilakukan survei langsung mendatangi warga suatu daerah yang memiliki faktor predisposisi otitis eksterna dan penelitian di lakukan dalam tempo waktu yang 
lebih lama sehingga mendapatkan hasil yang lebih akurat.

\section{DAFTAR PUSTAKA}

1. Soepardi EA, Iskandar N, Bashiruddin J, Restuti RD, (editor). Kelainan Telinga Luar. Dalam: Buku Ajaran IImu Kesehatan Telinga Hidung Tenggorokan Kepala Leher. $6^{\text {th }}$ Ed. Jakarta: Fakultas Kedokteran Universitas Indonesia, 2007. H .60-61.

2. Parize $P$, Chandesris MO, Lanternier F, Poire'e $\mathrm{S}$, at all. Antifungal Therapy of Aspergillus Invasive Otitis Externa: Efficacy of Voriconazole and Review. American Society for Microbiology. 2009.

3. R Mösges R, Nematian S, Eichel A. Treatment of acute otitis externa with ciprofloxacin otic $0.2 \%$ antibiotic ear solution. Institute of Medical Statistics Informatics and Epidemiology Faculty of Medicine University of Cologne, Germany. 2011.
4. Patton R, Mukerji S, Francis B, Quinn Jr, Quinn MS. Pediatric Acute Infectious Otitis Externa. Grand Rounds Presentation, UTMB, Dept of Otolaryngology, 2010.

5. Ardan, Juliarti, Satwika, Fian,Rosmana D,dkk. Otitis Eksterna. Dalam: Sinopsis IImu Kesehatan Telinga Hidung Tenggorokan. Bangka Belitung: Penerbit Buku Kedokteran AFJ, 2008.

6. Keith B, Holten, Gick J. Management of the Patient with Otitis Externa. Clinton Memorial Hospital Family Practice Residency, Wilmington, and the University of Cincinnati Department of Family Medicine, Ohio. 2001.

7. Rowlands S, Devalia H, Smith C, Hubbard R, Dean A. Otitis externa in UK general practice: a survey using the UK General Practice Research Database. British Journal of General Practice, London. 2011 